sun being magnified to five inches in diameter. Even with the 12 -inch refractor the occasions suitable for a critical examination are rare.

In front of the slit $I$ also brought the terminals of the secondary circuit of an induction coll, which were connected with a Leyden battery. The current through the primary wire of the Ruhmkorff was furnished by a Gramme machine. This arrangement permitted the production of a strong oxygen spectrum near the spectrum of the sun's limb.

The most obvious point to determine was whether the oxygen lines visible in the spectrum of the solar disc projected beyond the apparent limb of the sun as seen in the spectroscope; in other words, whether oxygen could be detected in the lower parts of the chromosphere. For this purpose I looked particu. larly at the bases of the prominences. I saw a large number of reversed lines, including some of the more delicate lines of Young's preliminary catalogue, but on no occasion could I be sure that the oxygen lines were seen outside of the limb. Of course, unless such an observation could be made in a perfectly tranquil atmosphere, certainty could not be attained. The experiments were terminated temporarily on account of getting my right arm caught in the engine, but they will probably be resumed next summer.

On examining Prof. Young's catalogue of chromosphere lines made at Sherman Station, in the Rocky Mountains, it appears that he does not note the great oxygen group near $\mathrm{G}$, and as his observations were made with remarkable accuracy and care, this would tend to corroborate the view that the bright-line spectrum of oxygen as seen on the sun's disc must have its upper limit close to the apparent spectroscopic limb of the sun.

UEnky Drafer

Ohservatory, IIastings-on-IIudson, New York, January 28

\section{Brain of a Fossil Mammal}

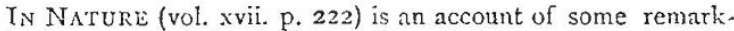
able characters of the brain of Coryphodon, as determined by l'rof. Cone, and recently published in the Proccutings of tive American Philosophical Society, vol. xvi. It may interest some of the readers of NATURE to know that the subject had been previously investigated by the writer, who published a description and figures of the brain cast of Coryphodon in the American Fournal of Science, vol. xi. p. 427, May, 1876 , more than a year befure the article above quoted appeared. Prof. Cope makle no reference to my paper, although periectly familiar with it. His figures moreover do not represent, even approximately, the brain of Cory phodon, owing to scrious erros in his observations, which were based upon an imperfect specimen, as I have shown elsewhere (American Fournal of Sicince, vol. xiv. p. $S_{3}$ ). One of the most glaring of these errors is seen in the supposed olfactory lobes which, as figured, include no smail part of the nasal cavities, and naturally add a very remarkable feature to this brain cast. The specimens from which my figures and description were taken are in excellent preservation, and are in the Yale College Museum, where they have been examined by Prof. Huxley and many other anatomists.

The attention called by NATURE to this paper of Prof. Cope's makes the present correction seem necessary for English readers, especially as the paper quoted is a typical one, illustrating the methods and work of its author.

Yale College, New Haven, Conn., February 7

\section{Origin of Tracheæ in Arthropoda}

In NATURE (vol. xvii. p. 284) is a notice of a work by Dr. Palmen, of Helsingfors, on the morphology of the tracheal system. From the wording of the notice it appears as if the views of Dr. Palmen as to the origin of trachere from skinglands, and as to the importance of Peripatus as an ancestral form of the Tracheata, were new to science. I was, to the best of my belief, the first to discover that Peripatus was provided with tracheæ; and in a paper on the structure and development of Piripatus capensis, published in the Phil. Trans. for 1874, I discussed the question of the origin of trachex, and put forward exactly similar views to those cited in your notice. These views have been adopted by Prof. Gegenbaur in his new edition of his "Grundriss der Vergleichenden Anatomie" (1878), in so far at least as that Peripatus is placed in a separate division of the Arthropoda, "the Protracheata." Haeckel, following Gegenbaur supposed his Protracheata to have been provided with tracheal gills, but the diffuse arrangement of the trachex in I'eripntus led me to conclude that the ancestral tracheata were terrestrial, and not aquatic, in habit, and that tracheal gills were comparatively late developments.

I am very glad to find that Dr. Palmen has arrived at similar results. Unfortunately, the place of publication of his treatise is omitted from your notice. It would be of valne if you saw fit to append the reference as a note to the present letter.
Exeter College, Oxford
II. N. MOSER.EY

[Dr. Palmen's paper was published in Helsingfors.- Ero.]

\section{The "Phantom" Force"}

III.

Wrme very clearly establishing that it is to the force urging a body that the potential energy which the body luts not, but can have, must properly be assigne' 3 , and calling it very a ppropriately the "energy of tension," "2 a very apposite remark (which I do not remember to have met with before) is added by " $X$ " in his concluding paragraphs. The body could not command this "force-work" in any position unless it had bich pul into the proper position to command it; and the actual chirgy spent in putting it there is the "energy of tension" which, although for. feited to the force, it can reclaim. In this view it is not surprising that potential energy should have the same terms for it. measurement as actual energy, since it is nothing but the actual energy which the body, or some agent operating upon it, has really lost; and if we pas from permanent forces to those ephemeral ones which physical agents can produce on an already. existing arrangement of bodlies, then, accorling to the existing configuration of the bodies when the force is generated, and in proportion to the "potential," or to the available statical energy developed, so is the work of the agent used to bestow this energy. In these cases of temporary "potentials" the actions are not actions at a distance, but through an internsediate medium, it may be strung with motion, and whth permanent forces, which have absorbed the work applied to put the intervening nedium, as it were, on the stretch, aud to develop the ephemeral enerisy of tension. But we recognise this very clearly (as for instance in charging well-insulated electrical conductors) only in the rare cases of reversible arrangements. The fatigue and exhaustion which we soon feel when holding out at arm's length a heavy weight (although we do no work upon the weight) ariscs, for example (like that of a galvanic battery exciting an electro-mamei and supporting a heavy armature), from two causes, the firs: of which, the excitation of the magnet and ammature, and the tightening of the muscies, or producing the requisite staticai energy for the occasion, absorb but a small portion of the work. The main expenditure is "frittered away" (a most expressive description of the process, which 1 owe to Prof. Tait) in aimless and random paths as heat, by the wasteful process of electrical or muscular currents afterwards kept up to maintain the excitation.

I have thus far sketched out a general view of physics (one which is perfectly adapted to satisfy its general requirements), in which self-balancing actions and reactions, only depending in intensity on the distance between their centres are supposed to be permanently implanted in pairs of material particles, a special case, or fresh assumption regarding the general system of forces contemplated in the Newtonian theory of mechanics, which either may, or may not be the complete theory of their action, but which assists the mind very greatly, by giving them a mechanical explanation, in forming true and correct preliminary notions of the two leading laws of the great modern science of energy. And here I may take the opportunity to mention that my own views of the relationship of modern physics in its various mutually dependent branches to that famous foundation of mechanics which Newton laid (or perhaps I should rather say, since the supremacy of mechanics is by no means yet conceded, of the Newtonian basis of mechanics to modern physics) have been mainly imparted and completed by a perusal of the excellent little manual on "Matter and Motion" by Prof. J. Clerk

\section{Continued from p. 322}

2 The term "statical energy" introduced by Sir W. Thomson (see a note in Prof. Tait's "Sketch of Thermodymamics," p. 52), and now proposed (NATURE, vol. xvi. p. 52I) by "W. P. O." to be substituted for the above, is of all the phrases yet used to denote it, the truest and simplest description of its real character. That it appertains to the force and not to the body is apparent both from this name and from the definition (which I have endeavoured to illustrate) that it is the "work" of the "agent," a property or possession of that individical, equal and opposite to, but not the sime as its 